\title{
Rehabilitasi Sebagai Alternatif Pemidanaan Terhadap Anak Korban Penyalahgunaan Narkotika Dalam Upaya Perlindungan Terhadap Anak
}

\author{
Andi Najemi, Kabib Nawawi, Lilik Purwastuti \\ Fakultas Hukum, Universitas Jambi, Indonesia
}

\begin{abstract}
ABSTRAK
Tujuan khusus penelitian untuk mengetahui dan menganalisis kedudukan anak penyalahguna narkotika serta melihat yang menjadi hal pokok pertimbangan hakim dalam menerapkan sanksi kepada anak korban penyalahguna narkotika. Rumusan masalah Bagaimanakaha kedudukan anak penyalahguna narkotika, Apakah sebagai korban atau sebagai pelaku, apa yang menjadi penilaian hakim lebih cendrung menerapkan pidana penjara, Bagaimanakah perlindungan hukum yang diberikan berkaitan dengan penerapan sanksi yang dijatuhkan. Jenis penelitian yang digunakan adalah penelitian penelitian normatif, Penggunaan metode ini dilakukan melalui kajian bahan-bahan hukum, baik bahan hukum primer, bahan hukum sekunder bahan hukum tertier. Pendekatan yang digunakan adalah: Pendekatan undang-undang atau statuta approach dan pendekatan kasus atau case approach yang dilakukan dengan melakukan telaah kasus-kasus yang berkaitan dengan isu ynag dihadapi yang telah mempunyai kekuatan hukum tetap. Hasil penelitian menujukkan bahwa Anak sebagai penyalah guna narkotika dianggap sebagai pelaku kejahatan bukan sebagai korban. Terhadap anak penyalah guna narkotika putusan penjara lebih dominan dijatuhkan, karena Hakim lebih memperioritaskan nilai kepastian hukum dibanding dengan nilai keadilan dan kemanfaatan. Dengan penjatuhan pidana penjara, maka hal tersebut tidak sesuai dengan semangat untuk mengutamakan keadilan restoratif, dan dianggap belum melindungi kepentingan anak.
\end{abstract}

Kata Kunci: Anak, penyalahgunaan narkotika, pidana penjara, rehabilitasi

\section{PENDAHULUAN}

\section{Latar Belakang Masalah}

Anak Sebagai penerus bangsa yang akan melanjutkan pembangunan yang dianggap memiliki tugas dan wewenang yang sangat penting serta memiliki karakter dan keistimewaan tertentu. Sebagai amanah Tuhan yang diberikan kepada setiap orang tua, maka sebagai orang tua harus memberikan pembelajaran yang sungguh-sungguh sedini mungkin.Ini karena anak memiliki hak atas kehidupan, kemerdekaan serta pengamanan dari siapapun tanpa terkecuali. ${ }^{1}$

Sebagai kaum muda yang akan melanjutkan perjuangan bangsa, maka setiap anak wajib memperoleh perlindungan hukum secara spesifik yang tidak sama dengan orang yang bukan anak-anak. Hal ini dikarenakan beberapa hal melekat pada anak, di antaranya adalah keadaan psikologis anak yang dianggap belum

\footnotetext{
${ }^{1}$ Abdussalam, HukumPerlindunganAnak, Restu Agung: Jakarta, 2007, hlm. 1
} 
sempurna. Berhubungan dengan hal tersebut, perlindungan hukum terhadap anak dianggap sebagai "upaya memberikan perhatian, pengawasan, pembimbingan terhadap kebebasan untuk menentukan sendiri masa depannya yang berkaitan dengan ketentramannya. ${ }^{2 \prime}$ Oleh karenanya, ketika anak bermasalah dengan hukum, maka perlindungannya dalam bentuk pendampingan wajib diberikan oleh negara, maka dalam pelaksanaannya tindakan yang dilaksanakan adalah tindakan yang memang terpenting untuk anak. Hal tersebut ditegaskan pula dalam pasal 3 ayat (1). Walaupun terjadi pelanggaran hukum yang dilakukan anak, tapi sejatinya tetap memperoleh perlindungan akan hak-haknya. Terkait ini, Maidin Gultom mengemukakan:

"Pada prinsipnya anak belum mampu menjaga dirinya sendiri dari berbagai hal dan dapat mengakibatkan kerugian dan penderitaan dalam berbagai hal dalam kehihidupannya. Melihat hal tersebut, maka anak memerlukan bantuan orang lain dalam menjaga dirinya. Termasuk apabila anak terlibat dalam pelaksanaan Peradilan Pidana. Anak memerlukan pendampingan agar terhindar dari kekeliruan dalam menetapkan norma hukum yang berlaku sehingga dapat mengakibatkan kerugian bagi dirinya."3

Berkaitan dengan hak-hak anak dan cara mendapatkannya, maka sudah ada beberapa aturan yang mengaturnya, diantaranya Undang-Undang No. 35 tahun 2014 tentang Perlindungan Anak dan Undang-Undang No. 11 Tahun 2012 tentang Sistem Peradilan Pidana Anak yang merupakan aturan tersendiri yang diberlakukan kepada anak yang melakukan suatu tindakan yang melawan hukum. Dalam aturan tersebut disebutkan bahwa anak yang dapat dipertanggungjawabkan adalah seseorang yang umurnya 12 tahun dan belum sampai 18 tahun. Terhadap anak tersebut berlaku prosedur peradilan tersendiri yang berbeda dengan peradilan yang bukan anak atau orang dewasa yang disebut dengan Peradilan Pidana Anak. Kekhususan pidana anak ini bertujuan agar anak mendapatkan perlindungan atas perkembangan keperibandiannya mengingat masa depan yang mereka miliki masih sangat panjang. Demikian pula, melalui perlakukan khusus ini, anak diharapkan tetap dapat dibimbing, agar kelak mampu menjadi anak yang sehat, cerdas, bertanggungjawab dan mempuyai kehidupan yang dapat dibanggakan.

Peraturan tersebut juga bertujuan untuk menegakkan yang memang seharusnya diberikan kepada anak agar prinsip kepentingan yang terbaik bagi anak dapat diimplementasikan, misalnya berhak untuk mendapatkan pendampingan dari orang tuanya. Perlindungan terhadap anak adalah langkah dan tindakan yang

${ }^{2}$ Lilik Purwastuti\& Sri Rahayu, “Reformasi Perlindungan Hukum Terhadap anak Sebagai Pelaku Tindak Pidana Dalam Peradilan Pidana Indonesia,"Inovatif Jurnal Ilmu Hukum, 2013, hlm 106

${ }^{3}$ Maidin Gultom, Perlindungan Hukum Terhadap Anak, Refika Aditama: Bandung, 2008, hlm. 2. 
diambil agar dapat melahirkan suasana yang memungkinkan terwujudnya hak dan kewajibannya secara wajar menurut perkembangan dan pertumbuhannya. ${ }^{4}$

Meningkatnya penyalahguna narkotika yang pelakunya anak mengharuskan langkah dan upaya real untuk memberikan pendampingan khusus bagi anak yang melakukan kejahatan, khususnya sebagai pelaku penyalahgunaan narkotika. Anak sebagai penyalah guna narkotika, dianggap sebagai orang dirugikan, Sehingga tidak selayaknya, dijatuhkan sanksi pidana, dan tidak disamakan dengan penyalah guna dewasa yang sesungguhnya. ${ }^{5}$

Menurut Undang-Undang Narkotika, pelaku penyalah guna narkotika juga dianggap sebagai korban. ${ }^{6}$ Heny Harsono menegaskan bahwa anak-anak yang menggunakan narkotika untuk dikonsumai sendiri dianggap bukan pelaku dan masuk kategori korban yang memang sewajarnya mendapatkan pendampingan. ${ }^{7}$ Sementara itu, aturan yang mengatur Perlindungan anak bahwa anak yang menjadi korban penyalah gunaan narkotika wajib mendapatkan perlindungan. Terkait hal tersebut, peradilan anak dibedakan dari peradilan yang biasa dilakukan pada orang dewasa. Kusno Adimenegaskan bahwa anak sebagai korban penyalahguna narkotika sepatutnya mendapatkan rehabilitasi. ${ }^{8}$

Sejauh menyangkut rehabilitasi, telah diatur dalam salah satu pasal yaitu Pasal 67 :" Mereka yang menjadi korban penyalahguna narkotika maupun zat adiktif lainnya, memperoleh penanganan tersendiri, dengan merujuk Pasal 59 ayat (2) huruf e, bahwa bentuk perlindungan yang diberikan dilakukan melalui upaya mencegah agar terhindar dari penggunaan narktika, memberikan perawatan, dan melakukan rehabilitasi." Orang menggunakan narkotika untuk kepentingan diri sendiri merupakan pelaku sekaligus korban, maka terhadap orang tersebut diberikan perlindugan khusus. Perlindungan tersebut berupa "penanganan secara serius, dan dilakukan pengobatan yang berbentuk rehabilitasi jasmani, rohani, medis dan sosial, serta mengantisipasi timbulnya penyakit yang dapat mengganggu kesehatan."

Rehabilitasi terhadap anak sebagai pelaku penyalahgunaan narkotika berujuan untuk menekan agar penggunaan narkotika serta obat-obatan terlarang dapat ditekan. Meski dalam kacamata hukum, anak diposisikansebagai korban, namun dalam peraturan perundang-undangan mereka disebutsebagaipelaku suatu tindak

\footnotetext{
${ }^{4}$ Maidin Gultom, Perlindungan Hukum Terhadap Anak - Dalam Sistem Peradilan Pidana Anak di Indonesia, Rafika Aditama, Bandung, 2014, hlm.40

${ }^{5}$ Dina Novitasari, Jurnal Hukum Khaira Ummah, Vol. 12, Tahun 2017, hlm. 97

${ }^{6}$ Adi Kusno. Diversi Sebagai Upaya Alternatif Penanggulangan Tindak Pidana Narkotika oleh Anak, Malang: UMM Press, 2009, hlm. 3.

${ }^{7}$ Heny Harsonodalam artikel Vinda Fitria Ananda, Eko Raharjo, Rini Fathonah, Perlindungan Hukum Terhadap Anak Sebagai Pelaku Tindak Pidana Penyalahgunaan Narkotika, Fakultas Hukum UNILA, 2018, hlm.2.
}

${ }^{8}$ Koesno Adi, Diversi Tindak Pidana Narkotika Anak, Setara Pess, Semarang, 2014, hlm. 23 
pidana. ${ }^{9}$ Terkait masalah ini, seorang anak berhak diberikan perlindungan baik karena menjadi korban akibat perbuatan orang lain maupun akibat dari perbuatan yang dilakukan diri anak itu sendiri, seperti penyalahguna narkotika. Pasal 1 angka 15 Undang-Undang Narkotika mendefinisikan, "penyalah guna narkotika adalah orang yang mengkonsumsi narkotika tidak sesuai dengan aturan" maka dapat diancam pidana, seperti rumusan dalam Pasal 127.

Saat ini, penyalahgunaan narkotika telah merambah ke berbagai usia. Penggunanya mulai dari usia muda hingga lanjut usia, sehingga memang dianggap dapat membahayakan kehidupan generasi muda. Berikut ini adalah tabel yang menunjukkan jumlah perkara penyalahgunaan narkotika yang dilakukan oleh anak selama 3 (tiga) tahun terakhir yang diproses di wilayah hukum Pengadilan Negeri Jambi:

Tabel 1. Putusan Hakim dalam Perkara Anak Penyalah Guna Narkotika 2016-201910

\begin{tabular}{cccc}
\hline No & Nomor Putusan & $\begin{array}{c}\text { Pasal Yang Dikenakan } \\
\text { Pada Anak }\end{array}$ & Jenis Putusan \\
\hline 1 & 2/Pid.Sus-Anak/2016/PN. Jmb & 127 ayat 1 UU No. 35 Th. & Penjara 8 bulan \\
2 & 14/Pid.Sus-Anak/2016/PN. Jmb & 2009 & Penjara 1 tahun \\
3 & 19/Pid.Sus-Anak/2016/PN. Jmb & Idem & Idem \\
4 & 20/Pid.Sus-Anak/2016/PN. Jmb & Idem & Penjara 1,2 tahun \\
5 & 23/Pid.Sus-Anak/2016/PN. Jmb & Idem & Penjara 1,4 tahun \\
6 & 24/Pid.Sus-Anak/2016/PN. Jmb & Idem & Penjara 1,4 tahun \\
7 & 26/Pid.Sus-Anak/2016/PN. Jmb & Idem & Penjara 1,4 tahun \\
8 & 41/Pid.Sus-Anak/2016/PN. Jmb & Idem & Penjara 1 tahun \\
9 & 12/Pid.Sus-Anak/2017/PN. Jmb & Idem & Penjara 10 bulan \\
10 & 13/Pid.Sus-Anak/2017/PN. Jmb & Idem & Penjara 10 bulan \\
11 & 19/Pid.Sus-Anak/2018/PN. Jmb & Idem & Penjara 1 tahun \\
12 & 23/Pid.Sus-Anak/2018/PN. Jmb & Idem & Penjara 1 tahun \\
13 & 8/Pid.Sus-Anak/2019/PN. Jmb & Idem & Rehabilitasi \\
\hline
\end{tabular}

Sumber: Pengadilan Negeri Jambi

Tabel di atas menunjukan bahwa terhadap anak penyalah guna narkotika, penjatuhan putusan penjara lebih dominan. Hal ini tentunya tidak sejalan dengan keinginan untuk mengutamakan keadilan restoratif dan menerapkan rehabilitasi kepada penyalah guna narkotika, padahal telah diatur dalam aturan Sistem

\footnotetext{
${ }^{9}$ Anang Iskandar, Penegakan Hukum Narkotika, Rehabilitatif Terhadap Penyalah Guna dan Pecandu, Refresif Terhadap Pengedar, Kompas Gramedia, Jakarta, 2019, hlm.21

${ }^{10}$ Pengadilan Negeri Jambi,"Sistem Informasi Penelusuran Perkara Pengadilan Negeri Jambi,” 2019.
} 
Peradilan dalam hal penerapan sanksi yang cocok yang diberikan dilaksanakan melalui upaya rehabilitasi. ${ }^{11}$

Berdasarkan data yang ada pada KPAI, Jumlah anak-anak yang menjalani hukuman pidana penjara dan yang ditahan jumlahnya cukup tinggi, yaitu setiap tahunnya berjumlah sekitar 6000 orang anak. Jumlah tersebut cukup mengkhawatirkan, mengingat anak-anak adalah harapan masa depan. Karena itu, pidana penjara sejatinya bukanlah tempat yang tepat bagi mereka. ${ }^{12}$

Selanjutnya Asep Syarifuddin Hidayat(et.al) menegaskan bahwa penjatuhan pidana penjara terhadap anak jelas tidak bisa disamakan dengan penerapan pidana penjara yang diterapkan kepada pelaku yang bukan anak. Hal ini karena sifat psikologis serta maksud dan tujuan anak berbeda dari pelaku yang bukan anak. Demikian pula dengan tingkat kemampuan memahami peraturan yang berlaku. Hal inilah semesetinya menjadi penilaian para pihak yang mempunyai kewenangan dalam melakukan perlindungan hukum berdasarkan Undang-Undang Nomor. 35 Tahun 2014 Tentang Perlindungan Anak. ${ }^{13}$

Hasil penelitian telah menunjukkan kalau penerapan pidana penjara telah teruji dapat menimbulkan dampak yang kurang baik terhadap anak dan akan sangat berdampak kepada pertumbuhan jasmani, mental, psikis, maupun lingkungan sosial mereka. ${ }^{14}$ Untuk penerapan sanksi terhadap anak, ada beberapa pilihan yang dapat diterapkan,di antaranya adalah tindakan berupa rehabilitasi.

Berdasarkan tabel 1 di atas, sebagian besar penyalah guna narkotika dari kalangan anak-anak tidak mendapatkan vonis rehabilitasi menurut aturan yang berlaku tetapi dengan penjara. Padahal aturan yang terdapat dalam UndangUndang Narkotika mengatur masalah upaya rehabilitasi. Oleh karenanya, penegakan hukum dengan mengedepankan rehabilitasi adalah jalan terbaik bagi anak yang terlibat dalam penyalahgunaaan narkotika. ${ }^{15}$. Penerapan rehabilitasi sebagai salah satu bentuk alternatif dari pemidannaan dan juga perwujudan perlindungan terhadap anak.

\section{Rumusan Masalah}

Berdasarkan apa yang dipaparkan di atas, maka permasalahan dalam penelitian ini dapat dirumuskan adalah sebagai berikut:

11 Abintoro Prakoso, Pembaruan Sistem Peradilan Pidana Anak, Laksbang Grafika, Yogyakarta, 2013, hal.89

${ }^{12}$ Sony Kusuma, “Anak Berhadapan dengan Hukum,”Hukum Online.com, Minggu, 09 Februari 2020.

${ }^{13}$ Asep Syarifuddin Hidayat, Samul Anam, Muhamad Ishar Helmi, "Perlindungan Hukum Terhadap Anak Sebagai Kurir Narkotika,"Jurnal Sosial dan Budaya UIN Syarif Hidayatullah Jakarta,Vol. 5 No. 3 (2018),hlm 4

${ }^{14}$ Hafrida, . "Pembinaan Narapidana Ana Di Lembaga Pemasyaraktan Anak Sei. Bulu Muara Bulian,"Jurnal Publikasi Pendidikan, Vol 5 No. 3, 2015. hlm. 40

${ }^{15}$ Ibrahim Fikma Edrisy, "Implementasi rehabilitasi Terhadap Anak Penyalahguna Narkotika,"Fiat Justisia Journal of Law, Volume 10, Tahun 2016, hlm. 320 
1. Bagaimanakaha kedudukan anak penyalahguna narkotika, Apakah sebagai korban atau sebagai pelaku?

2. Apa yang menjadi dasar penilaian hakim lebih cendrung menerapkan pidana penjara?

3. Bagaimanakah perlindungan yang diberikan kepada anak korban penyalahguna narkotika berkaitan dengan penerapan sanksi yang dijatuhkan?

\section{METODE PENELITIAN}

Penelitian ini yang menggunakan penelitian normatif, Penggunaan metode ini melalui kajian bahan-bahan hukum, baik bahan hukum primer, bahan hukum sekunder bahan hukum tertier.

\section{Pendekatan yang digunakan.}

Pendekatan yang digunakan adalah: 1). pendekatan undang-undang atau statuta approach dan sebagian ilmuan hukum menyebutnya dengan pendekatan yuridis, yaitu penelitian terhadap produk-produk hukum. ${ }^{16}$. 2). Selanjutnya dengan menggunakan Pendekatan konseptual, yaitu penelitian dengan melihat konsepkonsep hukum seperti; sumber hukum, fungsi lembaga, dan sebagainya, kemudian dengan menggunakan 3). Pendekatan kasus atau case approach, dalam pendekatan kasus yaitu dengan mengiventarisis kasus-kasus dan selanjutnya melakukan analisis terhadap kasus-kasus yang berkaitan dengan isu yang dihadapi yang telah mempunyai kekuatan hukum tetap. ${ }^{17}$ Apabila menggunakan pendekatan kasus, maka yang harus diperhatikan adalah dengan melihat putusan hakim dengan pertimbangan hukumnya.

\section{PEMBAHASAN}

\section{Anak Penyalahguna Narkotika Sebagai Korban}

Peraturan yang mengatur tentang Narkotika mengklasipikasikan orang yang mengkonsumsi narkotika untuk dipakai diri sendiri atau disebut sebagai penyalahguna termasuk dalam suatu kejahatan. Pengertian penyalahguna sebagaimana dimaksud dalam Pasal 1 angka 15 peraturan tersebut adalah "seseorang yang memakai narkotika yang tidak sesuai dengan aturan yang berlaku". yang berarti bahwa siapapun tanpa adanya pengecualian apabila mengkunsumsi narkotika tidak sesuai dengan aturan disebut sebagai penyalahguna. Aturan yang mengatur apabila seseorang menggunakan narkotika yang tidak sesuai dengan aturan yang berlaku dapat diancam dengan ketentuan Pasal 127 Undang

\footnotetext{
${ }^{16}$ Ibid., hal. 92

${ }^{17}$ Peter Mahmud Marzuki, Penelitian Hukum, Cet. 2, Kencana Prenada Media Group, Jakarta, 2006, hal. 94
} 
Undang narkotika. Ada beberapa kriteria yang dapat diancam dengan Pasal 127, yaitu pecandu narkotika adalah orang yang selalu mengkonsumsi narkotika dan tidak dapat melepaskan dirinya dengan barang tersebut, baik secara fisik maupun secara psikis (Pasal 1 angka 13), dan menurut penjelasan Pasal 54, korban penyalahgunaan narkotika adalah setiap orang pada mulanya tidak ada keinginan untuk memakai, tapi adanya bujukan, pemaksaan, kebohongan maupun ada atau tidak ada ancaman untuk memakainya..

Selanjutnya untuk dapat digolongkan hanya sebagai pemakai atau terlibat sebagai pengedar adalah melalui banyaknya barang bukti yang ditemukan. Untuk menentukan seseorang sebagai pemakai atau pengedar, maka yang menjadi dasar pertimbangannya dapat dilihat pada Surat Edaran Mahkamah Agung Nomor 4 tahun 2010 tanggal 7 April 2010. Oleh karena itu jika ketentuan-ketentuan yang diatur dalam aturan tersebut terpenuhi, maka dapat dikenakan Pasal 127.

Ketentuan Pasal 127 ayat (1), "Siapapun yang menggunakan narkotika golongan 1, akan dikenakan pidana penjara maksimal 4 tahun, untuk golongan dua, ancaman pidananya adalah pidana penjara maksimal 2 tahun, dan untuk penyalahguna golongan 3 ancaman pidananya adalah pidana penjara maksimal 1 tahun. Selanjutnya dalam ketentuan ayat (2), apabila hakim akan menjatuhkan sanksi, maka hakim tersebut wajib mempertimbangkan Pasal 54, 55 dan Pasal 103. Berkaitan dengan penerapan sanksi yang diberikan oleh hakim, maka hakim terlebih dahulu harus dapat membuktikan apakah si pelaku sebagai pengguna atau bukan. Jika hakim mempunyai bukti yang cukup membuktikan sebagai penyalahguna, maka wajib menjalani rehabilitasi medis dan rehabilitasi sosial. Dilihat dari peraturan tersebut, maka ada kewajiban bagi hakim untuk mempertimbangkan Rumusan Pasal 54, Pasal 55 dan Pasal 103. yang berarti bahwa terhadap penyalahguna disamping ancaman pidana penjara juga bisa dikenakan rehabilitasi.

Berkaitan dengan masalah anak sebagai penyalahgunaan narkotika, dalam perspektif viktimologi bahwa penyalahguna narkotika yang digunakan untuk dikonsumsi diri sendiri Menurut Sellin dan Wolfgang, seseorang yang mengkonsumsi hanya digunakan dikomsumsi sendiri, merupakan korban penyalahguna narkotika atau disebut "mutual victimization", yang berarti tidak ada korban lain selain dirinya sendiri. Seperti halnya tindak pidana lain, yaitu, perzinahan, dan pelacuran ${ }^{18}$ yang berarti sipelaku juga merupakan korban. Penjelasan yang dimaksud dengan korban dapat dilihat dalam suatu aturan yaitu Undang-Undang Nomor 13 Tahun 2006 Tentang Perlindungan Saksi dan Korban. yang dimaksud dengan korban adalah "setiap orang yang mendapatkan perbuatan yang tidak menyenangkan yang berupa penderitaan fisik, psikis, mental

${ }^{18}$ Dikdik M.Arief Mansur dan Elisatris Gultom, Urgensi Perlindungan Korban Kejahatan,,PT.Raja Grafindo Persada, Jakarta, 2007, hal. 206 . 
dan/atau kerugian ekonomi yang diakibatkan oleh suatu tindak pidana" Berdasarkan penjelasan tentang korban dalam Undang-Undang tersebut, maka seseorang bisa menjadi korban apabila ada tindakan orang lain yang berupa tidak pidana. Sementara dalam hal penyalahguna yang mengkonsumsi untuk digunakan untuk kepentingannya dirinya, tidak menimbulkan korban terhadap orang lain sehingga menjadi korban adalah dirinya sendiri. Berarti dalam hal ini tidak ada korban selain dirinya sendiri, sehingga penyalahguna narkotika tidak dapat dikategorikan sebagai pelaku kejahatan. Oleh karena itu diperlukan suatu perubahan aturan dalam hukum pidana yang memposisikan pecandu narkotika sebagai korban, bukan pelaku kejahahatan. ${ }^{19}$ Dengan demikian dapatlah dikatakan bahwa penyalah guna narkotika untuk digunakan sendiri terutama pelakunya anak merupakan korban yang perlu penanganan khusus berupa rehabilitasi medis dan rehabilitasi sosial. Selanjutnya peraturan yang mengatur tentang kewajiban rehabilitasi terhadap penyalahguna narkotika adalah SEMA No. 4 tahun 1990 Tentang Penempatan korban penyalahguna dalam lembaga rehabilitasi .Kedudukan Penyalahguna narkotika dalam Undang-Undang narkotika disamping sebagai pelaku sekaligus juga sebagai korban.

Berdasarkan tipologi korban yang diidentifikasikan berdasarkan kondisi dan status korban, terbagi menjadi 6 (enam),yaitu :

1. Unrelated victims, adalah tidak adanya hubungan sama sekali antara korban dan pelaku.

2 Provocative victims, adalah seseorang menjadi korban, karena adanya provokator dari orang lain yang mendorongnya.

3. Participating victims, adalah tingkah lakunya mendorong orang lain melakukan suatu perbuatan terhadap dirinya.

4. Biologically weak victims, adalah adanya kelemahan terhadap kondisi fisik, penyebab terjadinya korban.

5. Socially weak victims, adalah kedudukan sosial yang lemah di masyarakat menjadi penyebab terjadinya korban.

6. Self victizing victims, adalah dirinya menjadi korban akibat dari tindakan yang diperbuatnya sendiri. ${ }^{20}$

Dengan merujuk pendapat beberapa para ahli hukum, bahwa penyalahguna narkotika merupakan self-victimizing victims, yaitu seseorang menjadi korban akibat dari tindakan yang diperbuatnya sendiri. Namun, ada juga yang mengelompokkannya dalam victimless crime atau kejahatan tanpa menimbulkan

${ }^{19}$ Afni Zahra, RB Sularto, Penerapan Asas Ultimum Remedium Dalam Rangka Perlindungan Anak Pecandu narkotika, Jurnal Law Reform, Volume 13 Tahun 2017

${ }^{20}$ Moh Taufik Makarao,Suhasril, dan Moh Zakky A.S.,Tindak Pidana Narkotika, Galia Indonesia, Jakarta, 2013, hal.49 
korban karena biasanya setiap kejahatan pasti ada sasaran untuk menjadi korban. ${ }^{21}$ Selain itu, penyalahgunaan narkotika dapat diklasifikasikan dalam kejahatan tanpa menimbulkan korban atau kerugian terhadap orang lain. Penjelasan tentang kejahatan tanpa menimbulkan korban berarti kejahatan ini tidak ada satupun orang lain yang menjadi korban, namun korbannya adalah si pelaku sendiri. Sedangkan dalam katagori kejahatan dalam hukum pidana, bahwa suatu perbuatan yang dianggap jahat haruslah mengakibatkan timbulnya korban dan korban itu adalah orang lain, yang berarti apabila hanya diri pribadi sendiri yang menjadi korban, maka perbuatan tersebut tidak masuk kategori sebagai kejahatan. Oleh karena itu hakim yang memutuskan perkara tersebut, seharusnya tidak menerapkan pidana penajara kepada anak sebagai penyalahguna, tapi menerapkan rehabilitasi. Hal ini diperjelas dalam Pasal 3 ayat (1) Peraturan Kepala Badan Narkotika Nasional Nomor 11 Tahun 2014,. yang mengatur bahwa Pecandu dan Korban Penyalahgunaan Narkotika diberikan perlindungan berupa pengobatan, perawatan dan pemulihan dalam lembaga rehabilitasi. Selanjutnya diperkuat dengan Surat Edaran No. 7 tahun 2009, yang dinyatakan oleh Ketua Mahkamah Agung “ Tahanan maupun narapidana narkotika yang berada di Lembaga Pemasyarakatan hampir sebagian besar termasuk kategori pengguna dan korban.". Oleh karena itu penerapan rehabilitasi adalah langkah yang tepat. Berdasarkan beberapa hasil penelitian menunjukkan bahwa rehabilitasi terhadap anak dianggap mampu untuk membebaskan korban pengguna narkotika dari ketergantungan. Oleh karena itu Rehabilitasi terhadap anak sebagai korban penyalahguna narkotika merupakan" suatu proses pengobatan yang ampuh untuk membebaskan dan menyelamatkan anak dari ketergantungan narkotika serta merupakan suatu wujud kepedulian akan kehidupannya, sehingga anak tersebut dapat mengintegrasikan dirinya dalam tertib sosial dan terbebas dari ketergantungan narkotika.

Anak korban penyalahguna narkotika berhak untuk memperoleh hak untuk direhabilitasi, dengan beberapa pertimbangan, yaitu :

1. Bahwa anak sebagai korban tidak boleh dihalangi untuk mendapatkan haknya

2. Bahwa Rehabilitasi merupakan salah satu hak dari anak yang dapat memberikan pemulihan terhadap anak, sehingga hak tersebut wajib diberikan kepada anak sebagai korban

3. Bahwa rehabiltasi merupakan pemulihan terhadap korban dari ketergantungan penggunaan narkotika, istilah tersebut digunakan oleh hukum lokal maupun hukum luar.

${ }^{21}$ Dikdik M.Arief Mansur dan Elisatris Gultom, Urgensi Perlindungan Korban Kejahatan,, PT.Raja Grafindo Persada, Jakarta, 2007, hal. 49 
4. Bahwa pelaksanaan rehabilitasi merupakan pemulihan dari ketergantungan penggunaan narkotika, dan dalam pelaksanaan rehabilitasi tersebut tidak ditemukan adanya pelemahan hak-hak korban ${ }^{22}$

Namun dalam kenyataannya anak sebagai korban penyalahguna narkotika, berdasarkan hasil dari beberapa penelitian, anak dianggap sebagai pelaku kejahatan bukan sebagai korban, sehingga Hakim lebih cendrung menjatuhkan pidana penjara dibandingkan dengan sanksi tindakan ataupun rehabilitasi..

\section{Penilaian Hakim Dalam Penerapan Sanksi Terhadap Anak Penyalahguna Narkotika}

Berdasarkan tipologi korban menurut status dan identifikasi korban, bahwa anak sebagai penyalahguna narkotika, adalah menjadi korban akibat dari tindakan yang diperbuatnya sendiri, artinya akibat dari perbuatan yang dilkukannya sendiri, maka mereka dianggap dianggap sebagai pelaku kejahatan. Pengaturan tentang Penyalahguna narkotika dalam Undang-Undang Narkotika disatu sisi dianggap sebagai pelaku kejahatan dan dilain sisi dianggap sebagai korban penyalahguna narkotika. Berkaitan dengan anak yang dianggap sebagai pelaku penyalahgunaan narkotika dalam penerapan stelsel sanksi bagi anak, tidak ada pengaturan dalam Undang-Undang Narkotika yang mencantumkan secara khusus tentang stelsel sanksi bagi anak penyalahguna atau yang menggunakan narkotika tanpa hak. Meskipun, tidak dicantumkan secara khusus tentang stelsesl pemidanaan terhadapa anak penyalahguna, namun terdapat beberapa pasal pengecualian yang khusus diberlakukan terhadap anak yang umurnya belum mencapai 18 tahun. Untuk anak sebagai korban penyalahguna diberlakukan stelsel sanksi dalam Undang-Undang Narkotika dan diberlakukan juga Undang-Undang Sistem Peradilan Pidana Anak sebagai ketentuan khusus yang diterapkan kepada anak. Terhadap anak sebagai penyalahguna narkotika dalam hal penjatuhan sanksi pidana, menimbulkan pro dan kontra di kalangan masyarakat, karena dalam hal ini mempunyai konsekuensi yang sangat luas bagi si anak. baik menyangkut sikap, perbuatan maupun cap pelaku kejahatan yang ada dalam masyarakat dan juga dalam diri anak tersebut ${ }^{23}$. Terhadap anak penyalahguna narkotika akan diproses berdasarkan UndangUndang Nomor 11 tahun 2012 tentang sistem peradilan pidana anak. Berdasarkan aturan tersebut, maka anak harus diperlakukan secara manusiawi, adanya pembimbingan, pendampingan dan adanya sarana prasarana khusus. Penerapan sanksi harus mempertimbangkan untuk kepentingan yang terbaik bagi si anak.

${ }^{22}$ Wayan "gendo" Suardana, Urgensi vonnis Rehabilitasi Terhadap Korban Napza di Indonesia, Http: //www. che gendovara Blog Archive, diakses tanggal 27 Juli 2020

${ }^{23}$ Merry Natalia Sinaga, Ide Dasar Double Track System : Sanksi Pidana Dan Tindakan Sebagai Sistem Pemidanaan Terhadap Pelakukejahatan Penyalahgunaan Narkotika 
Hasil penelitian yang telah dilakukan (Tabel 1) menunjukkan bahwa putusan pengadilan yang dijatuhkan menempatkan pidana penjara paling dominan dijatuhkan. Padahal pidana penjara kurang tepat diberikan kepada anak, apalagi anak dianggap sebagai korban. Pidana penjara hanya diterapkan kepada pelaku penyalahguna yang sudah dewasa, bukan kepada pelaku penyalahguna anak. ${ }^{24}$ Dengan menerapkan KUHP dan menjatuhkan pidana penjara terhadap anak sebagai penyalahguna narkotika berarti tidak memeberikan pendidikan terhadap anak dan tidak menjadikan anak lebih lebih baik, serta dapat meningkatkan kejahatan yang dilakukan anak.

Seharusnya anak korban penyalahgunaan narkotika tidak diterapkan pidana penjara dan menghindarkan anak untuk ditempatkan di Lembaga Pemasyarakatan. Sesuai dengan amanat Perlindungan Anak, dinyatakan bahwa sebaiknya anak diberikan rehabilitasi oleh lembaga dan institusi yang telah ditunjuk oleh pemerintah. Hal ini sesuai dengan pasal 67 UU Perlindungan Anak ${ }^{25}$

Perlindungan terhadap anak yang terlibat dalam suatu pelanggaran hukum yang berupa penyalahguna narkotika diatur di dalam Pasal 64 Undang-Undang Nomor 35 Tahun 2014 tentang Perlindungan Anak yang menyatakan, bahwa; Pertama, setiap anak harus diperlakukan secara kemanusiaan sesuai dengan harkat dan martabat dan hak-hak anak. Kedua, adanya orang yang ditunjuk secara khusus yang memberikan pendampingan Ketiga, tersedianya sarana dan prasarana yang diberikan secara khusus kepada anak.. Keempat, apapun bentuk tidakan yang dijatuhkan kepada anak, maka tindakan tersebut merupakan tindakan yang paling baik untuk kepentingan yang terbaik bagi anak. Kelima, adanya laporan berupa pengamatan dan catatan yang dilakukan secara kontinyu terhadap kelanjutan kasus anak yang berkonflik dengan hukum. Keenam, merahasiakan identitas anak dari pemberitaan agar anak terhindar dari cap atau stigma sebagai pelaku, ketujuh, menghindarkan anak dari penangkapan, penahanan atau penjara, kecuali tidak ada lagi upaya yang dapat dilakukan dan merupakan upaya terakhir dengan waktu yang tidak lama."

Dengan demikian anak korban penyalahguna narkotika dalam hal penjatuhan pidana merupakan jalan yang paling akhir diberikan dan penerapannya dilakukan dengan waktu yang paling pendek. Penjatuhan pidana penjara dianggap kurang pas, karena kurang memberikan perlindungan terhadap anak. Perlindungan anak merupakan bentuk konkrit adanya rasa adil dalam kehidupan di masyarakat. Oleh karena itu diprioritaskan dalam berbagai bidang kehidupan bernegara dan bermasyarakat. Tindakan dalam memberikan perlindungan terhadap anak akan

24 Ardhi Prasetyo, Diversi Tindak Pidana Narkotika Terhadap Anak, hal. 12, diakses tgl 29 Juli 2020

${ }^{25}$ Lihat Pasal 67 UU Perlindungan Anak 
menimbulkan konsekuensi hukum, yang dalam hubungannya dengan hukum positf maupun hukum yang hidup dalam masyarakat. ${ }^{26}$

Penanggulangan terhadap penyalahguna narkotika yang dilakukan oleh anak dengan menerapkan sanksi pidana sebagai alat penanggulangan pada prinsipnya adalah suatu pilihan yang sulit, karena dengan menggunakan peradilan pidana anak kurang memperoleh keadilan yang maksimal dan mengesampingkan kebutuhan dan ketenteraman anak, sehingga dianggap tidak sesuai sebagai sarana penanggulangan penyalahgunaan narkotika yang dilakukan oleh anak. ${ }^{27}$

Seorang anak mempunyai hak dan kewajiban secara wajar dan manusiawi, maka dalam hal memberikan perlindungan kepada anak yang merupakan suatu langkah dalam memberikan perlindungan agar anak dapat memperoleh hak yang dimilikinya dan dapat menjalankan kewajibannya secara wajar dan manusiawi, maka perlu dilakukan pendidikan yang edukatif meliputi aspek-aspek kemanfaatan, kepribadian, moral, akhlak dan kepedulian terhadap lingkungan sosial serta memberikan pembinaan, pembimbingan, pendampingan, penyertaan dan pengawasan kepada anak.

Untuk hal itu, maka agar anak mendapatkan perlindungan dalam prosese peradilan pidana, sehingga kebutuhan, keinginan dan harapan anak tetap diprioritaskan dan dapat dilaksanakan, menurut Sudarto bahwa: "semua bentuk kegiatan yang dilakukan dalam proses peradilan anak ini, mulai dari proses di kepolisian, kejaksaan ataupun di pengadilan, harus berlandaskan pada suatu esensi demi kebutuhan, ketentraman dan kepentingan anak. jadi hakim yang akan menerapkan pidana ataukah tindakan harus didasarkan pada pertimbangan dengan mengutamakan untuk ketentraman dan kenyamanan anak yang bersangkutan, tanpa mengabaikan kebutuhan, kepentingan rakyat umum". ${ }^{28}$ Berdasarkan hal tersebut, perhatian, kesehatan, dan keselamatan anak merupakan prioritas utama, tidak boleh dikorbankan demi kepentingan apapun, karena apabila dibiarkan justru akan mengakibatkan bentuk kejahatan lain atau korban lain

Mencermati tabel di atas, menunjukkan bahwa terhadap kasus penyalahguna narkotika, yang didakwa pada setiap kasus berdasarkan pasal 127 Undang-Undang no.35 Tahun 2009 Tentang Narkotika dan menjatuhkan pidana penjara. Melihat putusan yang dijatuhkan hakim, maka menimbulkan pertanyaan mengapa hakim lebih dominan menerapkan pidana penjara, padahal penerapan pidana penjara tidak membawa manfaat. Untuk itu sebaiknya dihindarkan terhadap anak-anak yang melakukan kenakalan terlebih kenakalan penyalahguna narkotika yang sebenarnya diyakini bahwa mereka adalah berstatus sebagai korban.

26 Nashriana, Pertimbangan Hakim Dalam Menjatuhkan Putusan Pidana Penjara Terhadap Anak Pelaku Penyalahgunaan Narkoba, hal. 23, Diakses tgl 29 Juni 2020

27 Ibid

${ }^{28}$ Op.cit, hlm. 25 
Dari seluruh putusan yang dijatuhkan oleh Hakim berupa pidana penjara terhadap anak, menunjukkan kalau Hakim yang memutuskan perkara tersebut adanya pengaruh dari pemikiran positivis, Artinya apabila suatu aturan sudah dirumuskan dalam Undang-Undang, maka aturan tersebut menjadi dasar hukum untuk memutus suatu perkara, dan menjadi pertimbangan utama, dalam artian bahwa apabila sudah dirumuskan dalam Undang-Undang, maka menjadi dasar untuk diterapkan, termasuk kepada anak-anak korban penyalahguna narkotika. Putusan hakim yang yang umumnya berupa pidana penjara, padahal anak sebagai pengguna merupakan korban, sudah sepantasnya Treatment yang dijatuhkan berupa rehabilitasi, karena dianggap lebih bermanfaat diberikan dibandingkan dengan sanksi Pidana.

Dalam hal menjatuhkan putusan terhadap anak penyalahguna narkotika, ada beberapa hal yang dipertimbangkan hakim. Menyangkut tentang pertimbangan Hakim, bahwa seharusnya hakim lebih memprioritaskan nilai keadilan dan nilai kemanfaatan dibanding dengan nilai kepastian hukumnya. ${ }^{29}$ Namun dalam kenyataannya selama ini, Hakim lebih memprioritaskan nilai kepastian hukum dibandingkan dengan nilai keadilan dan kemanfaatan, padahal untuk sanksi kepada anak, yang harus dipertimbangkan adalah apakah putusan yang dijatuhkan menimbulkan kebaikan atau manfaat terhadap anak. hal yang demikian mengingat anak diperlakukan secara khusus, penuh dengan kasih sayang dari orang-orang sekitarnya.

Gustav Radbruch mengemukakan berkenaan dengan kemanfaatan hukum, "sesuatu yang dapat menimbulkan kebaikannya atau manfaatnya"30. Berkenaan dengan penyelesaian kasus penyalahguna narkotika yang dilakukan oleh anak, dapat dilihat dari segi kebaikannya dan kekurangaannya, atau segi manfaat dan segi keburukannya dari penyelesaian perkara tersebut. Manfaat terhadap penyelesaian kasus tersebut dapat ditinjau dari berbagai aspek, tentunya dengan pertimbangan yang memang terbaik bagi anak, artinya penjatuhan pidana penjara terhadap anak dtinjau dari sisi manfaat atau kebaikannya, Anak sebagai penyalahguna bila dilihat dari segi manfaatnya, tidak mendapatkan manfaat apapun dari penerapan sanksi berupa pidana penjara tersebut.

Penerapan sanksi berupa pidana penjara kepada anak akan menimbulkan kerugian-kerugian. Oleh karena itu sebaiknya hakim menerapkan putusan terhadap anak berupa rehabilitasi. Dengan penjatuhan pidana penjara terhadap anak, berarti mengabaikan kepentingan anak untuk dapat tumbuh dan berkembang dengan baik dan berkualitas, dapat menganggu kepribadiannya, mendapatkan stigma sebagai pelaku kejahatan sehingga dapat merusak mentalnya, dan bergaul dengan

${ }^{29}$ Ibid

${ }^{30}$ Gustav Radbruch dalam Usman dan Andi Najemi, Mediasi Penal di Indonesia: Keadilan,Kemanfaatan, dan Kepastian Hukumnya, hal.7 Undang: Jurnal Hukum ISSN 2598-7933 (online); 2598-7941 (cetak)Vol. 1 No. 1 (2018): 65-83, DOI: 10.22437/ujh.1.1.65-83 
anak-anak di Lembaga Pemasyarakatan yang memang pelaku kejahatan. Oleh karena itu menjatuhkan pidana penajara dan menempatkan anak penyalahguna narkotika di Lembaga Pemasyarakatan dianggap kurang memberikan perlindungan terhadap anak, Menurut Amir Syarifudin "Anak yang mengkonsumsi narkotika sebaiknya tidak dijatuhkan sanksi berupa pidana penjara, karena hal itu kurang memberikan dampak positif terhadap prilaku pada pribadi anak. Oleh karena itu Solusi terbaik adalah dengan cara memberikan rehabilitasi kepada mereka, agar mereka menjadi sadar dan bisa berubah ${ }^{31}$. yang berarti bahwa penajatuhan pidana penajara terhadap anak penyalahguna narkotika kurang memberikan perlindungan terhadap anak.

\section{KESIMPULAN DAN SARAN}

Anak penyalahguna narkotika termasuk self-victimizing victims, adalah anak tersebut menjadi korban akibat dari tindakannya sendiri. Dalam artian kejahatan tanpa menimbulkan korban (crime without victim). Artinya adanya suatu perbuatan yang masuk kategori kejahatan, tapi tidak menimbulkan korban bagi orang lain, maka perbuatan tersebut tidak masuk kategori suatu kejahatan, sehingga anak penyalahguna narkotika dianggap sebagai korban bukan pelaku kejahatan, maka tindakan yang tepat adalah rehabilitasi

Anak penyalahguna narkotika dianggap sebagai korban, maka tidak tepat apabila dijatuhkan pidana penjara, karena akan menimbulkan kerugian-kerugian apabila hakim menjatuhkan pidana penjara, dan kurang memberikan perlindungan terhadap anak. Solusi terbaik hakim menjatuhkan putusan terhadap anak berupa rehabilitasi.

Selanjutnya, Anak penyalahguna narkotika hendaknya dianggap sebagai korban bukan sebagai pelaku, maka dalam penerapan sanksinya sebaiknya diterapkan rehabilitasi bukan pidana penjara. Karena kurang memberikan perlindungan terhadap anak. dan dilihat dari kemanfaatannya tidak memberikan manfaat bagi anak.

\section{DAFTAR PUSTAKA}

Abdussalam, Hukum Perlindungan Anak, Restu Agung, . Jakarta, 2007.

Adi , Kusno. Diversi Sebagai Upaya Alternatif Penanggulangan Tindak Pidana Narkotika Oleh Anak, Malang: UMM Press, 2009

${ }^{31}$ Amir Syarifudin, Rehabilitasi Solusi Bagi Pengguna Narkoba, dalam Nashriana, Pertimbangan Hakim Dalam Menjatuhkan Putusan Pidana Penjara Terhadap Anak Pelaku Penyalahgunaan Narkoba, hal. 23, Diakses tgl 29 Juni 2020 
Anang Iskandar, Penegakan Hukum Narkotika, Rehabilitatif Terhadap Penyalah Guna dan Pecandu, Refresif Terhadap Pengedar, Kompas Gramedia, Jakarta, 2019

Abintoro Prakoso, Pembaruan Sistem Peradilan Pidana Anak, Laksbang Grafika, Yogyakarta, 2013

Bahder Johan Nasution, Metode Penelitian Ilmu Hukum, Mandar Maju, Bandung, 2008 Maidin Gultom, Perlindungan Hukum Terhadap Anak, Refika Aditama, Bandung, 2008 Koesno Adi, Diversi Tindak Pidana Narkotika Anak, Setara Pess, Semarang, 2014

\section{Jurnal Ilmiah}

Asep Syarifuddin Hidayat, Samul Anam, Muhamad Ishar Helmi, Perlindungan Hukum Terhadap Anak Sebagai Kurir Narkotika, Jurnal Sosial dan Budaya UIN Syarif Hidayatullah Jakarta Vol. 5 No. 3 (2018).

Amir Syarifudin, Rehabilitasi Solusi Bagi Pengguna Narkoba, dalam Nashriana, Pertimbangan Hakim Dalam Menjatuhkan Putusan Pidana Penjara Terhadap Anak Pelaku Penyalahgunaan Narkoba

Dina Novitasari, Jurnal Hukum Khaira Ummah, Vol. 12, Tahun 2017.

Heny Harsono dalam artikel Vinda Fitria Ananda, Eko Raharjo, Rini Fathonah, Perlindungan Hukum Terhadap Anak Sebagai Pelaku Tindak Pidana Penyalahgunaan Narkotika, Fakultas Hukum UNILA, 2018

Hafrida, Yulia Monita, dan Elizabeth Siregar. "Pembinaan Narapidana Anak Di Lembaga Pemasyaraktan Anak Sei. Bulu Muara Bulian,"(Hasil peneilitan). Jurnal Publikasi Pendidikan, Vol 5 No. 3, 2015.

Lilik Purwastuti, Sri Rahayu, Reformasi Perlindungan Hukum Terhadap anak Sebagai Pelaku Tindak Pidana Dalam Peradilan Pidana Indonesia, Inovatif Jurnal Ilmu Hukum, 2013.

Ibrahim Fikma Edrisy, Implementasi rehabilitasi Terhadap Anak Penyalahguna Narkotika, Fiat Justisia Journal Of Law, Volume 10, Tahun 2016

Nashriana, Pertimbangan Hakim Dalam Menjatuhkan Putusan Pidana Penjara Terhadap Anak Pelaku Penyalahgunaan Narkoba

Merry Natalia Sinaga, Ide Dasar Double Track System: Sanksi Pidana dan Tindakan Sebagai Sistem Pemidanaan Terhadap Pelaku Kejahatan Penyalahgunaan Narkotika, Jurnal Penelitian Pendidikan Sosial Humaniora, Vol.3 No.1 Tahun 2018

Sony Kusuma, Anak Berhadapan dengan Hukum, Hukum Online.com, Minggu, 09 Februari 2020.

\section{Peraturan Perundang-Undangan}

Undang-Undang Nomor 35 Tahun 2009 tentang Narkotika

Undang-Undang No. 35 Tahun 2014 Perubahan Undang-Undang No. 23 Tahun 2003 tentang Perlindungan Anak

Undang-Undang No. 11 Tahun 2012 tentang Sistem Peradilan Pidana Anak 